\title{
TTL Note Accounts and the Money Supply Process
}

\author{
RICHARD W. LANG
}

S SINCE November 1978, when the Treasury changed its cash management procedures, the Federal Reserve has been faced with less uncertainty in managing the week-to-week volume of bank reserves. Weekly swings in the Treasury's balances at Federal Reserve Banks have been smaller, and the decreased volatility of these balances has reduced the Federal Reserve's uncertainty about reserve positions. Consequently, Federal Reserve (Fed) open market operations that are conducted to offset the effects of fluctuations in Treasury balances on bank reserves have not had to be as large as in previous years.

This decreased volatility is the result of the introduction of the Treasury Tax and Loan (TTL) Investment Program, which enables the Treasury to invest its funds in interest-bearing notes of commercial banks. The TTL note program was designed to achieve two objectives: the payment of interest on the Treasury's cash balances at commercial banks and the stabilization of the Treasury's balances at the Federal Reserve.

The introduction of the TTL note program also has affected the relationship between bank reserves and the money supply. This article discusses the implications of this change in Treasury cash management for the Federal Reserve and the banking system.

\section{TREASUPY BALANCES AT BANKS}

\section{Background}

Originally, TTL accounts at commercial banks were called Liberty Loan accounts. Created by Congress in 1917 in the Liberty Loan Act, these accounts facilitated the issuance of Treasury securities (Liberty bonds) to finance government expenditures during World War I. ${ }^{1}$ Proceeds of the sale of Liberty bonds

${ }^{1}$ Both before and after the Liberty Loan Act, the Treasury has held demand deposits at commercial banks other than those reported as Liberty Loan accounts (or Tax and Loan accounts ). These other deposits declined in tuse after World War II, although they were used to some extent between 1972 and 1976. Balances in these deposit accounts between 1972 and were deposited in Liberty Loan accounts at commercial banks instead of in the Treasury's account at the Federal Reserve Banks. Thus, the deposits used to pay for the bonds remained in the banking system until spent by the government. The Liberty Loan accounts avoided an increase in the volatility of deposit and bank reserve flows which could have resulted from the war-financing effort. Moreover, this system also encouraged banks to purchase Liberty bonds for their own accounts and to act as underwriters of these Treasury issues in selling them to the public. ${ }^{2}$

In 1918, the Treasury extended the provisions governing the use of Liberty Loan accounts, allowing federal income and excess profits taxes to be deposited in them. The accounts were renamed War Loan Deposit accounts, and banks were required to pay interest on the funds in these accounts at the rate of 2 percent per annum. These balances were essentially interest-earning demand deposits.

When the Banking Act of 1933 prohibited the payment of interest on demand deposits, interest payments on War Loan Deposit accounts were also eliminated. Furthermore, the Banking Act of 1935 made these accounts at member banks subject to the same reserve requirements as those placed on private demand deposits.

Balances in War Loan Deposit accounts increased rapidly during World War II with the increased issuance of government debt to finance the war. After the war, Congress continued to broaden the use of these accounts to include deposits of more types of tax receipts, including withheld income taxes and So-

1976 were sniall relative to batances in TTL accounts and are ignored in the subsequent discussion. Treasury holdings of time deposits at banks, also relatively small, are likewise ignored.

In addition, the congressional act that created the Liberty Loan accounts abolished reserve requirements against all U.S. government deposits at member banks. Federal Reserve Bulletin (June 1917), p. 458 . 


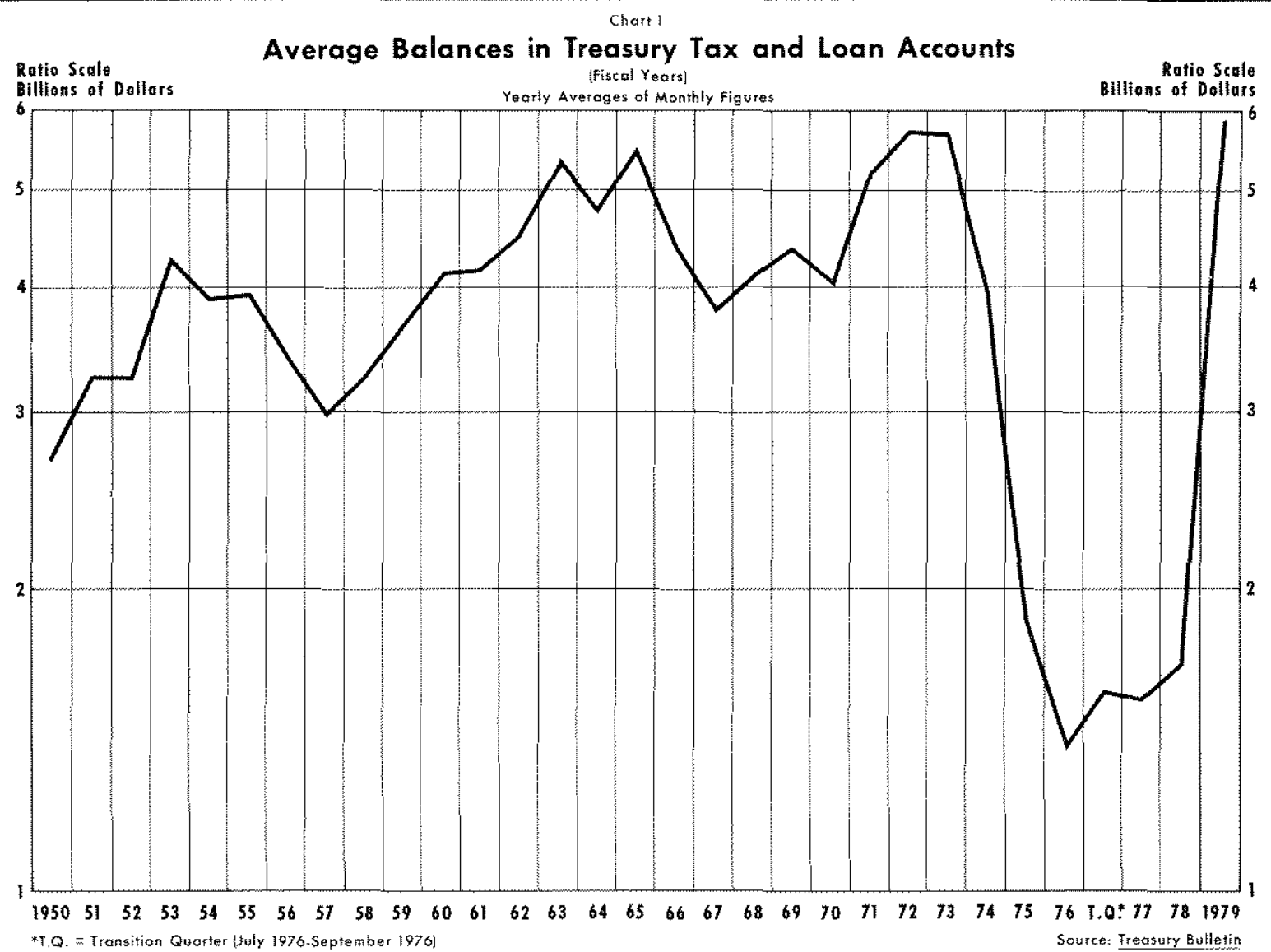

cial Security payroll taxes. In 1950 , the accounts were renamed Tax and Loan accounts.

Currently, TTL accounts continue to serve as deposit accounts for the proceeds from the sale of U.S. government securities (particularly savings bonds), as well as for such varied tax receipts as withheld income taxes, corporate income taxes, excise taxes, employer and employee Social Security taxes, federal unemployment taxes, and taxes under the Railroad Retirement Act of 1951.

\section{Treasury Management of TTL Accounts}

One of the main objectives of establishing the original Liberty Loan accounts was to minimize fluctuations in the aggregate levels of bank deposits and reserves that can result from sales of government bonds. This objective later was extended to include minimizing fluctuations in deposits and reserves that can result from tax payments. If the Treasury had no accounts with commercial banks, proceeds of bond sales and tax payments would be deposited in the Treasury's account at Federal Reserve Banks. Deposits thus would be transferred out of the banking system, and bank reserves would decline. These funds would be returned to the banking system only when the Treasury issued checks drawn upon its account to make purchases or transfer payments. ${ }^{3}$

The Federal Reserve can use open market operations to offset such fluctuations in bank reserves. The Open Market Desk can purchase government securities (which increases bank reserves and deposits) when the Treasury's balance at the Fed increases, and can sell government securities when the Treasury's balance at the Fed declines. Such "defensive" open market operations effectively neutralize the effect that shifts in Treasury balances between commercial banks and the Fed have on bank reserves.

Prior to 1974, the Treasury tended to minimize tluctuations in its balances at the Fed by maintaining funds at commercial banks until they were disbursed. Consequently, the Fed had only to make relatively small defensive open market operations to smooth out

3 For a summary of the effects of these transfers on the balance sheets of commercial barks and the Federal Reserve, see Dorothy M. Nichols, Modern Money Mechanics, Federal Reserve Bank of Chicago (June 1975), pp. 18-19. 


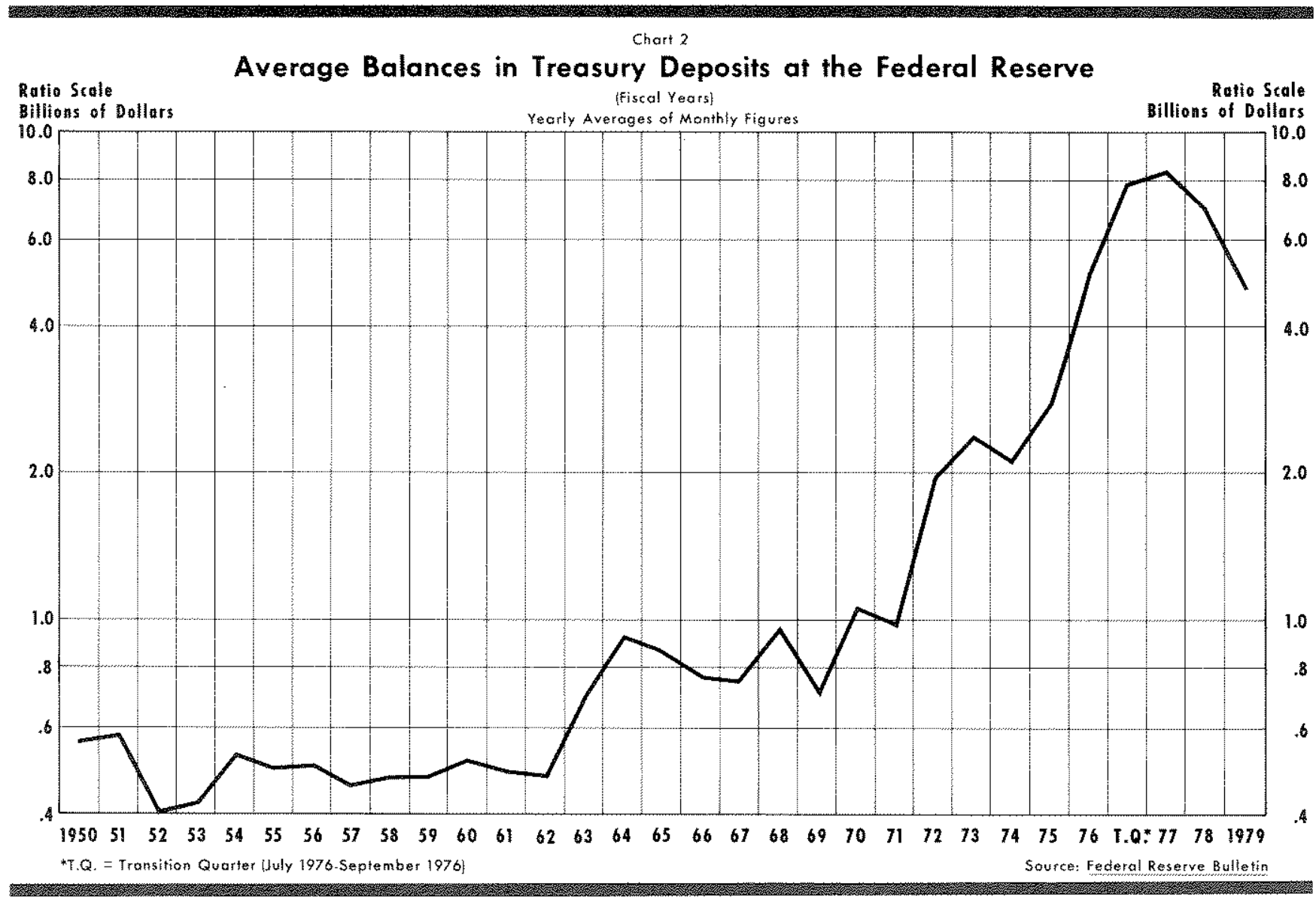

changes in bank reserves associated with the Treasury's cash management. ${ }^{4}$

Although the Treasury earned no interest on these commercial bank accounts after 1933, it generally felt that various services provided by banks (without charge) compensated for the lack of explicit interest earnings. Such services included the sale and redemption of savings bonds, collection of taxes, and handling of Treasury checks and other Treasury securities. Two Treasury studies of TTL accounts, one in 1960 and another in 1964, found that these accounts were not a source of profit to banks; the cost of providing services to the Treasury was generally greater than the value of the TTL accounts to the banks. A similar study in 1974, however, found the reverse, primarily because of increased market interest rates and the exclusion of certain items that were previously connted as costs of providing bank services to the Treasury. ${ }^{5}$

"See, for example, "Tax and Loan Accounts-Government Balances Managed to Avoid Upsetting Money Markets," Federal Reserve Bank of Dallas Business Review (November 1973), pp. 7-11.

TReport on Treasuny Tax and Loan Accounts, Services Rendered by Banks for the Federal Government and Other Re-
In order to increase its return from TTL accounts, the Treasury proposed in 1974 that Congress permit TTL balances to earn explicit interest. While Congress debated the Treasury's proposal, the Treastry changed its cash management procedures to reduce its balances at commercial banks (chart 1). The Treasury began to quickly shift funds deposited into TTL accounts to its account at the Fed. Average Treasury balances at the Fed and their volatility increased substantially after 1974 (chart 2). Swings in the weekly Treasury balance at the Fed, which averaged $\$ 533$ million in 1974, more than doubled in 1975 to an average of $\$ 1,388$ million (table 1 ). ${ }^{6}$

The Treasury viewed its increased balances at the Fed as a way to earn implicit interest on its funds. The Fed would offset the decline in bank reserves result-

lated Matters, Treasury Department, June 15, 1960; Report on Treasury Tax and Loan Accounts and Related Matters, Treasury Department, December 21, 1964; Report on a Study of Tax and Loan Accounts, Treasury Department, June 1974. For a discussion of these, studies, see Peggy Brockschnidt, "Treasury Cash Balances," Federal Reserve Bank of Kansas City Monthly Review (July-August 1975), pp. 12-20.

0 The same pattern of volatility before and after 1974 is also exhibited by the standard deviations of the weekly levels, or changes in levels, of Treasury deposits at the Fed. 
ing from such a shift of Treasury balances by increasing its portfolio of government securities (to stabilize either the federal funds rate or the level of bank reserves). With a larger portfolio of interest-earning assets, Federal Reserve income would rise. Since the Federal Reserve turns over its earnings after expenses to the Treasury as "interest" on the issuance of Federal Reserve notes (currency), the Treasury expected its "income" from the Federal Reserve to increase under this system.

This approach to managing the Treasury's balances increased defensive open market operations and complicated both the management of bank reserves and the short-run stabilization of the federal funds rate. ${ }^{7}$ As weekly swings in Treasury balances at the Fed became larger, weekly swings in Federal Reserve hold. ings of government securities (the major source of bank reserves and the monetary base) also increased (table 1). The increased volatility of the Treasury's balance at the Fed made the prediction of its effect on bank reserves more difficult. At times the Fed requested that the Treasury redeposit funds into TTL accounts, so that the Fed could avoid making direct purchases of securities to maintain its desired level of bank reserves in the face of these shifts. ${ }^{8}$

\section{The TTL Note Program}

Congress passed legislation in October 1977 that enabled the Treasury, "for cash management purposes, to invest any portion of the Treasury's operating cash for periods of up to ninety days in obligations of depositaries maintaining Treasury tax and loan accounts secured by a pledge of collateral acceptable to the Secretary of the Treasury as security for tax and loan

'See, for example, William R. McDonough, "Treasury Cash Balances - New Policy Prompts Increased Defensive Operations by Federal Reserve," Federal Reserve Bank of Dallas Business Review (March 1976), pD. 8-12; Joan E. Lovett, "Treasury Tax and Loan Accounts and I"ederal Reserve Open Market Operations," Federal Reserve Bank of New York Ouarterly Review (Summer 1978) pp. 43-44; AnnwMarie Meulendyke, "The Impact of the Treasury's Cash Management Techniques on Federal Reserve Open Market Operations," paper presented to the Federal Reserve System Committee on Financial Analysis, November 1977.

8Meulendyke, "The Impact of the Treasury's Cash Marage. ment Techniques," pp. 14-16. The Fed generally prefers to arrange security repurchase agreements (RPs) with banks and government security dealers, rather than to make direct purchases of securities, in offsetting "technical" factors that affect bank reserves, including shifts in Treastry deposits. RPs, however, require that banks and dealers have sufficient unpledged government securities to use as collateral. Such collateral was not reatily available ir sufficient quantity to offset the shifts in Treasury deposits that occurred after 1974. Rather than making direct purchases at these times, the Fed asked the Treasury to redeposit funds into TTL accounts at barks.

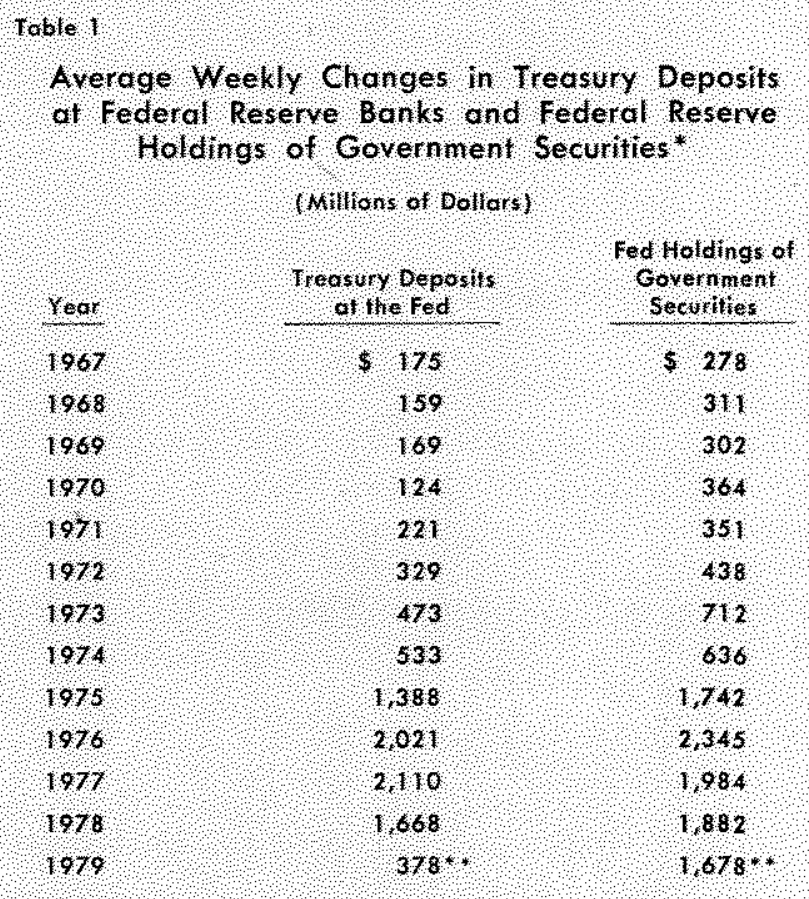

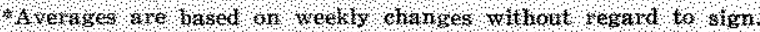

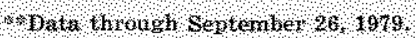

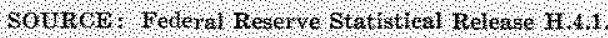

accounts ... .9 Congress also permitted the Treasury to pay fees for certain services for which banks previously were not compensated explicitly. The program was not implemented, however, until November 1978 , after Congress appropriated funds to permit the Treasury to reimburse banks and other depositaries for these services. ${ }^{10}$

Under the new program, banks have two options for handling Treasury funds: a remittance option and a note option. Under the remittance option, funds deposited in a bank's TTL account are transferred to the district Federal Reserve Bank after one business day. Banks selecting this option pay no interest on these funds, but member banks must hold required reserves against them, just as they did under the old program.

Under the note option, funds deposited in TTL accounts are transferred to open-ended, interest-bearing note accounts at the same bank after one business

19ublic Law 95-147, Congressional Record, October 11, 1977, pp. S16914-516920.

10The TTL note program was also extended to allow participation of certain savings and loan associations and credit unions. Participation of these thrift institutions, however, has been minor. Only 30 savings and loans and 4 credit unions participated as of June 30,1979 , according to a Treasury. Federal Reserve survey: "TTL Release No. 20," Department of the Treasury, August 3,1979 . 
day. For that one business day, the funds are treated the same way as the old TTL accounts: banks pay no interest to the Treasury on them, and member banks are required to hold reserves against them. Once the funds are credited to the note account, however, banks must pay interest on these funds at a rate 25 basis points below the prevailing weekly average federal funds rate, but member banks are not required to hold reserves against them.

Although note balances are payable on demand, the Treasury has attempted to establish a regular pattern of withdrawals from these note accounts, similar to the pattern of withdrawals it had established prior to 1974. ${ }^{11}$ In the first 10 months of 1978 , the average time that TTL balances remained in commercial banks was less than two days. Since their introduction in November 1978, the time that TTL note balances have remained in commercial banks has averaged over six days. ${ }^{12}$

After the introduction of the TTL note accounts, the Treasury reversed its previous cash management procedures. Treasury balances at the Fed fell substantially between October 1978 and January 1979 , while Treasury balances in the banking svstem rose (charts 1 and 2). In the absence of offsetting Federal Reserve actions, bank reserves (and the monetary base) would have increased. The Federal Reserve offset this increase in bank reserves, however, by selling government securities in the open market. Treasury deposits at the Fed declined by $\$ 11.6$ billion between October 1978 and January 1979, and Fed holdings of Treasury securities declined by about $\$ 10$ billion.

Since November of last year, the volatility of Treasury balances at the Fed has declined substantially (table 1). ${ }^{13}$ This tends to reduce the size of defensive open market operations, as indicated by the decline in 1979 in the average weekly changes in Fed holdings of government securities (table 1 ). The reduction in the magnitude of the swings in the Treasury's balance at the Fed and the plan to re-establish a

11 For a discussion of the pre-1974 schedule of withdrawals, see "Tax and Loan Accounts - Government Balances Managed to Avoid Upsetting Money Markets," Federal Reserve Bank of Dallas Business Review (November 1973), pp. 7-1I. For a discussion of the current system, see Joan $\mathbf{E}$. Lovett, "Treasury Tax and Loan Accounts and Federal Reserve Open Market Operations," Federal Reserve Bank of New York Qtarterly Review (Summer 1978), pp. 44-46.

12"TTL Release No. 20," Department of the Treasury, August 3, 1979 .

13 Again, the same pattern of volatility before and after November 1978 is exhibited by the standard deviations of the weekly levels, or changes in levels, of Treasury deposits at the Fed. regular pattern of withdrawals from note accounts will reduce the Fed's uncertainty about the effect of the Treasury's cash management on bank reserve positions. The decreased volatility of Treasury balances at the Fed should improve the Fed's prediction of its effect on bank reserves and, consequently, can be expected to improve its ability to achieve a desired level of bank reserves in the short rm. Furthermore, this change in Treasury cash management is expected to improve the Federal Reserve's ability to execute monetary policy, whether the Fed seeks some rate of growth of bank reserves associated with a desired rate of money growth, or seeks to stabilize or obtain a desired level of the federal funds rate.

\section{TTL NOTE ACCOUNTS AND THE MONEY SUPPLY PROCESS}

The new TTL program has affected not only the Federal Reserve's management of bank reserves, but also the relationship between bank reserves and the money stock. The responsiveness of the money stock to Federal Reserve actions that change the monetary base was altered, other things being equal, by the introduction of TTL note accounts. A standard model of the money supply process can be used to investigate the effect of the introduction of the TTL note program on the money stock. (see appendix). In this model, the money stock (M1) is equal to the product of the monetary (source) base (B) and the money multiplier $(\mathrm{m})$ :

$$
\mathrm{M} 1=\mathrm{mB}
$$

As noted earlier, the introduction of TTL note accounts led to a transition period in which the proportion of Treasury deposits held at commercial banks changed relative to its deposits at the Fed. As a result, the level of the monetary base (bank reserves plus currency in circulation) would have risen, other things being equal. For a given level of the money multiplier, this increase in the monetary base would have resulted in an increase in the money stock (see appendix). Through defensive open market operations, however, the Fed essentially offset this shift in Treasury deposits.

Changes in Treasury deposits at commercial banks, however, can affect both the reserve ratio and the Treasury deposit ratio, which are included in the money multiplier (see appendix, equation A.2). With the introduction of TTL note accounts, Treasury deposits at commercial banks include two accounts: deposits in regular TTL accounts and deposits in TTL note accounts. 
The Board of Governors of the Federal Reserve System amended its regulations in May 1978 to provide that TTL note accounts not be regarded as deposits subject to reserve requirements (Regulation D) or to the limitation of the payment of interest on deposits (Regulation Q). These amendments, however, do not affect the status of funds in regular TTL accounts prior to their investment in interest-bearing notes under the new program. For the one day before funds are either remitted to the Treasury's account at the Fed or placed in a TTL note account, member banks must treat the funds as demand deposits and maintain required reserves against them. This differential treatment of note accounts and regular TTL accounts affected the level of the money multiplier as the Treasury changed its cash management procedures.

\section{TTL Note Accounts and the Level of the Money Multiplies}

In the standard money multiplier framework, one can show (see appendix) that the introduction of TTL note accounts increases the level of the money multiplier, but only to the extent that Treasury funds are shifted out of regular TTL accounts at member banks into the new note accounts at member banks. The rise in the level of the money multiplier occurs because required reserves are reduced as deposits are shifted out of reservable regular TTL accounts into nonreservable note accounts. Consequently, the money multiplier depends on the composition of Treasury deposits in the banking system, not just on the level of Treasury deposits at banks.

The effect of the introduction of TTL note accounts on the ratio of demand deposits to bank reserves is illustrated in exhibit 1, which shows a simplified example of the changes in the balance sheet of member commercial banks as Treasury funds are shifted from regular TTL accounts to TTL note accounts. In panel A of exhibit 1, banks initially have deposit labilities of $\$ 1,000$, with $\$ 900$ in demand deposits of the nonbank public and $\$ 100$ in regular TTL accounts. Assuming that reserve requirements are 10 percent and that banks are fully loaned up (have no excess reserves), banks' assets include $\$ 100$ in required reserves and $\$ 900$ in loans and securities. The ratio of private demand deposits (which are included in the money stock) to bank reserves is equal to 9 in panel A. Were there no currency in the economy, this ratio would be the money multiplier.

With the introduction of TTL note accounts (exhibit 1, panel B), half of the Treasury's funds are

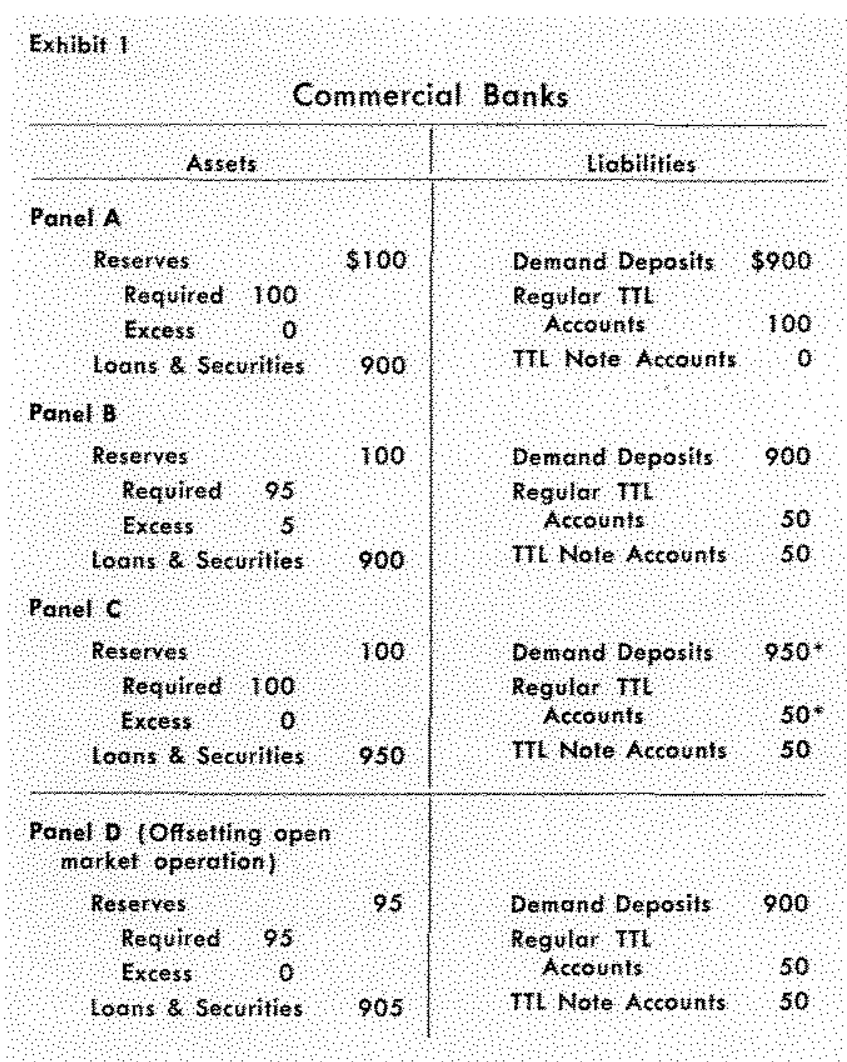

shifted into note accounts. Since there is no reserve requirement against TTL note deposits, there are now excess reserves of $\$ 5$. If banks expand their loans and deposits to eliminate these excess reserves (panel C), and if all the deposit expansion occurs in demand deposits of the nonbank public, demand deposits expand to $\$ 950 .{ }^{14}$ The ratio of demand deposits to reserves is now equal to 9.5 . With no cumency in the economy, this ratio indicates an increase in the money multiplier due to the introduction of TTL note accounts. In other words, the same anount of monetary base can now support a larger volume of deposits.

This increase in the ratio of demand deposits to bank reserves occurs even if the Federal Reserve absorbs the excess reserves released by the introduction of the note accounts (panel B) via open market operations. If the Fed sells securities to the banks to eliminate the $\$ 5$ of excess reserves (panel D), bank reserves decline to $\$ 95$, loans and securities increase to $\$ 905$, and demand deposits remain at $\$ 900$. The ratio of demand deposits to bank reserves again indicates an increase in the money multiplier due to the introduction

\footnotetext{
14 If regular TTL balances increase as demand deposits of the nonbank public expand (in order to maintain some new ratio of Trensury deposits to demand deposits), this result is altered somewhat. The inclusion of other types of deposits (such as tine and savings deposits) also alters this result.
} 
of TTL note accounts, since the ratio has increased from 9 (panel A) to 9.47 (panel D).$^{15}$

As the Treasury adapted its cash management procedures to the note account program, the average monthly regular TTL balance fell while the average monthly note balance rose. This shift, however, was not very large, amounting to only about a $\$ 1.2$ billion decline in the average monthly TTL balance at member banks since November 1978, compared with the average over the previous 18 months. This shift was also a relatively small proportion of the average monthly level of total note balances, which has averaged over $\$ 6$ billion since November 1978. This small decline in regular TTL balances is not surprising, considering that since 1974 the Treasury had reduced its regular TTL balances by quickly shifting these balances to the Federal Reserve Banks. Consequently, only small further reductions in average TTL balances were possible.

The $\$ 1.2$ billion shift in average monthly TTL balances at member banks implies only a small reduction in required reserves of the banking system. The decline in required reserves depends on the required reserve ratio on demand deposits and on the decline in regular TTL accounts at member banks (appendix, equation A.11). Since reserve requirements on demand deposits of member banks range between 7 percent and 16.25 percent, the decline in required reserves is between $\$ 84$ million and $\$ 195$ million. ${ }^{16}$ In comparison, total required reserves were over $\$ 38$ billion in October 1978.

Although the effect of the introduction of note accounts on the money supply process is to raise the level of the money multiplier, thereby increasing the level of the money stock, these effects are estimated to have been small. With reserve requirements ranging between 7 percent and 16.25 percent, the increase in the money multiplier ranges between 0.0016 and 0.0037 , respectively. In comparison, the money multiplier in October 1978 was approximately 2.6212. Based on the above changes in the money multiplier and a monetary (source) base of $\$ 137.8$ billion in October 1978, the level of the money stock could have increased, due to the change in the multiplier alone, by between $\$ 220$ million and $\$ 511$ million as a result of the introduction of note accounts (see appendix,

\footnotetext{
1\$The difference in this ratio from that in panel $\mathrm{C}$ is due to the earlier assumption about the expansion of deposits; see footnote 14 .

I0rThese estimates (and the ones that follow) ignore shifts of TTL balances between banks of different sizes having different reserve requirement ratios on demand deposits.
}

equation A.19) ${ }^{17}$ In comparison, the money stock in October 1978 was $\$ 361.2$ billion.

Other factors affecting the money supply process since last November have worked in the opposite direction and have had a greater impact on the money multiplier and the money stock. Last November, the Federal Reserve imposed a supplementary 2 percent reserve requirement on large-denomination time deposits ( $\$ 100,000$ or more), which tended to lower the money multiplier. The automatic transfer service (ATS) between checking and savings accounts, also introduced in November, again tended to lower the money multiplier. ${ }^{18}$ The net effect of these changes has been to reduce, rather than to increase, the money multiplier.

\section{TTL Note Accounts and the Variability of the Money Multiplier}

The introduction of TTL note accounts also has an impact on the money supply process by affecting the short-run variability of the money multiplier around tax payment dates. This effect is again the result of the absence of reserve requirements against note accounts. However, the shift in deposits that is of interest here is not between regular TTL and note accounts, but between private demand deposits and note accounts.

Under the TTL program, tax payments by bank customers result in transfers of funds from private demand deposits into a TTL account, generally at the same bank. Since private demand deposits are included in the definition of the money stock, but U.S. government deposits are not, such transfers initially reduce the money stock.

Prior to November 1978, reserve requirements on private demand deposits and government deposits were the same, so that the bank's required reserve position was not affected. Consequently, the monetary base initially was not affected by such transfers. Prior

\footnotetext{
${ }^{17}$ The figure of $\$ 137.8$ billion for the monetary (source) base is the figure reported by the Federal Reserve Bank of St. Lowis for the sonce base. The Board of Governors (BOG) monetary base for October 1978 was $\$ 137.5$ billion. The St. Louis soutce base and the BOG monetary base differ in their treatment of vault cash. The results reported here are essentially the same using the BOG figure. For a discussion of the differences between the two series, see Albert $E$. Burger, "Alternative Measures of the Monetary Base," this Review (June 1979), pp. 3-8.

${ }^{18}$ Scott Winuingham, "Automatic Transfers and Monetary Poliey," Federal Reserve Bank of Kansas City Monthly Review (November 1978), pp. 18-27; John A. Tatom and Richard W. Lang. "Automatic Tratsfers and the Money Supply Process," this Review (February 1979), pp. 2-10.
} 
Exhibil?

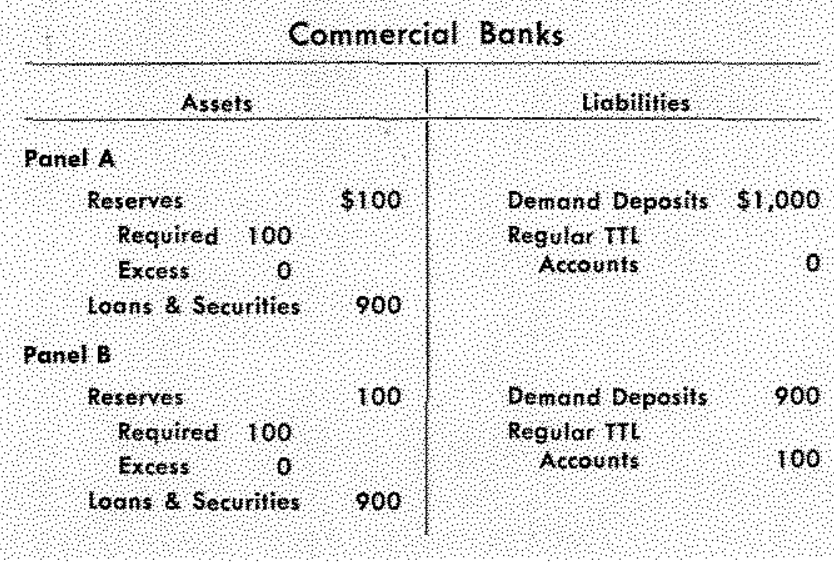

to 1974 , however, the decline in the demand deposit component of the money stock that resulted from these transfers was reflected in a temporary decline in the money multiplier.

This can be illustrated using the ratio of demand deposits to bank reserves in a simplified balance sheet of the banking system (exhibit 2). It is again assumed that banks are "loaned up," so that desired excess reserves are zero. As taxes are paid out of private demand deposits, the Treasury's TTL balance rises by $\$ 100$ but required reserves are unchanged (panel B). Consequently, the ratio of demand deposits to bank reserves declines from 10 to 9 , which represents a decline in the money multiplier. In this case, there is no upward (or downward) pressure on the federal funds rate since banks' required reserves are unaffected. ${ }^{19}$

From 1974 to November 1978, the Treasury's policy was to quickly transfer TTL balances out of the banking system to its accounts at the Fed. This procedure would have reduced bank reserves and put upward pressure on the federal funds rate, were it not for the Fed's offsetting open market operations. By restoring the reserves to the banking system, the money multiplier was unchanged. This is illustrated in exhibit 3 .

In panel $\mathrm{C}$ of exhibit 3 , banks become deficient in required reserves as taxes paid into TTL accounts are transferred to the Fed. When the Fed offsets this reserve drain by purchasing securities (panel D), the ratio of demand deposits to bank reserves is 10 , the

\footnotetext{
10If taxpayers borrow the $\$ 100$ from the banks to pay their taxes in exhibit 2, the ratio of demand deposits to bank reserves (and the money multiplier) would still decline since required reserves would increase to $\$ 110$. This is the case even if the Federal Reserve provides the resulting increased required reserves to the banks via open market operations. (In this case, the Fed's reserve-supplying operation would be offsetting upward pressure on the federal funds rate).
}

Extibit 3

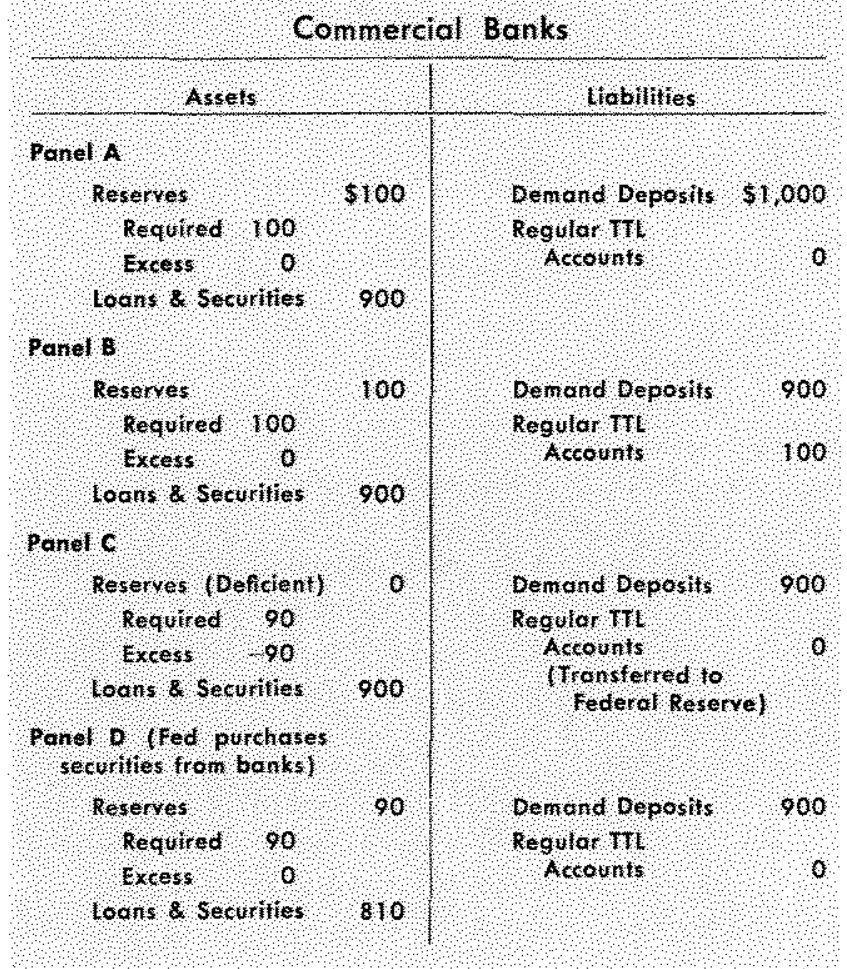

same as its original value (panel A). ${ }^{20}$

Under the current TTL program, tax payments that result in transfers out of private demand deposits into TTL note accounts will lower required reserves. If the Federal Reserve does not absorb these excess reserves in response to downward pressure on the federal funds rate, the banking system will use them to expand loans and deposits. The resulting expansion of the money stock will offset the decline in the money stock from the payment of taxes, so that the money multiplier again remains unchanged. ${ }^{21}$ This is illustrated in exhibit 4.

As tax payments are made out of private demand deposits, they flow (after one business day) into TTL note accounts (panel C). Since note accounts are not

20 Even without offsetting open market operations, the ratio of demand deposits to bank reserves (and the money multiplier) would have been unchanged. In this case, the banks oans and demand deposits would contract until required reserves and demand deposits were in the same proportion as before. This was not the procedure followed by the Federal Reserve, however.

If taxpayets borrow the $\$ 100$ from the banks to pay their taxes in exhibit 3 , the results are essentially the same: upward pressure on the federal funds rate would be offset by the Fed's open market operations, and the ratio of demand deposits to bank reserves (and the money multiplier) would be unchanged.

21 This assumes that there are no shifts of demand deposits from one bank into note balances at another bank having a different reserve requirement ratio against demand deposits. 


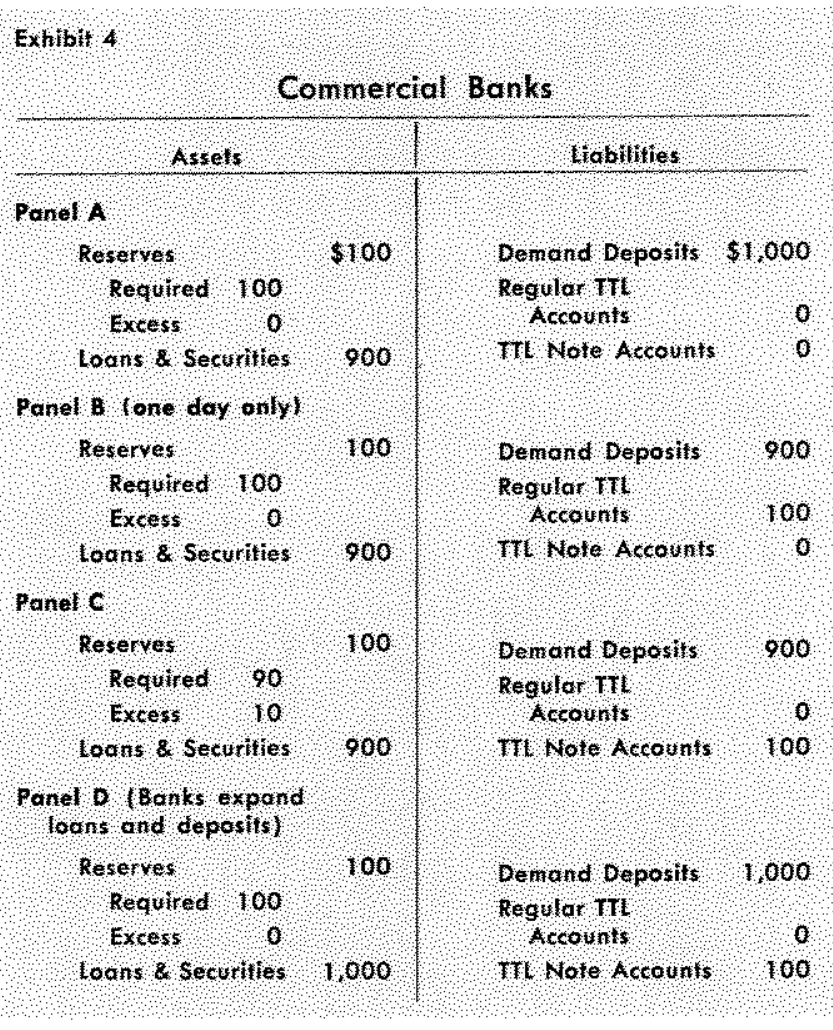

subject to reserve requirements, excess reserves increase. When banks eliminate these excess reserves by expanding loans and deposits (panel D), the ratio of demand deposits to bank reserves is 10 , the same as its original value, which indicates that the money multiplier is unchanged by such tax payments. ${ }^{22}$

In summary, the TTL program prior to 1974 resulted in short-run variations in the money multiplier around tax payment dates, with no initial change in bank reserves (or the monetary base). In order to maintain the same level of private demand deposits in the banking system after tax payment dates, the Federal Reserve would have had to supply additional reserves by purchasing government securities. From 1974 to November 1978, the Treasury's cash management procedure resulted in no short-run variations in the money multiplier, but could have resulted in large variations in bank reserves and the monetary base as balances in TTL accounts were shifted to the Fed. These po-

\footnotetext{
${ }^{22}$ It is also clear that if the Federal Reserve absorbed the excess reserves (panel $C$ ) via open market operations, the ratio of demand deposits to bank reserves (and the money multiplier) would also be unchanged from its original value (panel A).

If taxpayers borrow the $\$ 100$ from the banks to pay their taxes in exhibit 4, the ratio of demand deposits to bank reserves (and the money multiplier) is unchanged. In this case, however, no excess reserves are generated as taxes flow into TTL note accounts since demand deposits inerease by the same amount. Hence, there is no downward (of upward) pressure on the federal funds rate.
}

tential yariations in the monetary base were offset by Fed open market purchases of securities. In order to maintain the same level of private demand deposits in the banking system after tax payment dates, however, the Fed again would have had to supply even more reserves to the banks by purchasing additional securities.

Compared with the TTL program prior to 1974, the current program has reduced the short-run variability of the money multiplier around tax payment dates. Furthermore, bank reserves and the monetary base are unaffected around tax payment dates, in contrast to the 1974-78 cash management procedure. Finally, the same level of private demand deposits in the banking system will prevail after the tax payment date as before, provided the Fed allows the banking system to expand loans and deposits to reduce its excess reserves. The Federal Reserve need not supply additional reserves, then, in order to maintain the same level of demand deposits.

If the Fed seeks to smooth or confine fluctuations in the federal funds rate around tax payment dates, its actions would be different under the new TTL program than under either of the previous programs, since pressures on the federal funds rate are different. ${ }^{23}$ Prior to 1974 , there was no initial effect on the federal funds rate as taxes flowed into TTL accounts. Between 1974 and November 1978, there was upward pressure on the federal funds rate as TTL balances flowed out of the banking system into the Fed. Since then, there has been downward pressure on the federal funds rate as taxes flowed into TTL note accounts and excess reserves increased. To stabilize the federal funds rate under the current TTL program, then, the Fed would have to sell government securities to decrease banks' excess reserves. Prior to November 1978, the Fed would have had to purchase securities (the 1974-78 case) or make no purchases or sales (the pre1974 case).$^{24}$

\section{SUMMART AND CONCLUSTONS}

The Treasury's new cash management procedure has reduced the uncertainty faced by the Federal Reserve in achieving a desired level of bank reserves, compared with the cash management procedure adopted in 1974. Treasury balances at Federal Re-

\footnotetext{
23See text above and footnotes 19,20 , and 22 .

24 In the event that taxpayers borrowed from banks to pay their taxes (see footnotes 19,20 , and 22 ), the Fed would have had to sell securities to stabilize the federal funds rate around tax payment dates, both before 1974 and between 1974 and November 1978. In this case, there would be no pressure on the federal funds rate under the current TTL program.
} 
serve Banks have been reduced, and changes in these accounts have become less volatile since the new TTL note program went into effect in November 1978. This program has improved the Federal Reserve's ability to execute monetary policy, whether the Fed is seeking a rate of growth of bank reserves associated with a desired rate of money growth, or is seeking to stabilize or obtain a desired level of the federal funds rate.

Since there are differential reserve requirements against TTL note accounts and regular TTL accounts, the introduction of note accounts has affected the money supply process via the money multiplier. Other things being equal, the money multiplier would have risen as a result of the introduction of TTL note accounts, although the estimated increase is small. Other things were not equal, however - a supplementary reserve requirement on large-denomination time deposits was imposed, and ATS accounts were introduced in November 1978 as well. These other factors have more than offset the effect of the introduction of note accounts, so that the money multiplier has declined since November 1978.

Furthermore, as tax payments flow into TTL accounts, short-run movements of required reserves, the money multiplier, and the federal funds rate are different under the new note program than under the TTL program prior to 1974 . Since there is no reserve requirement against TTL note balances, required reserves fall, and the money multiplier remains unchanged as tax payments flow out of private demand deposits into note accounts. Since reserve requirements previously were the same for demand deposits and TTL balances, required reserves remained unchanged, and the money multiplier declined as tax payments were made into TTL accounts. Consequently, Federal Reserve actions around tax payment dates will be different under the current TTL program than under previous Treasury cash management procedures.

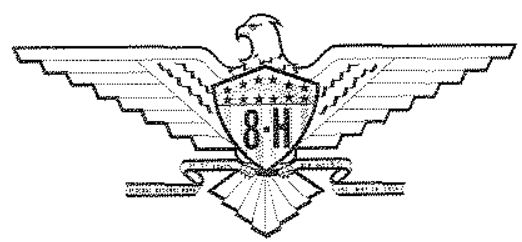




\section{APPENDTX}

This appendix derives the effect of the introduction of Treasury Tax and Loan (TTL) note accounts on the money multiplier. A standard model of the money supply process is employed, in which the money stock (MI) is the product of the monetary (source) base and a money multiplier (m).

(A.1) $\mathrm{Ml}=\mathrm{mB}$

The money muttiplier is given by:

$$
\begin{aligned}
& \text { (1.2) } \mathrm{m}=\frac{1+k}{n(1+1+g)+k} \\
& \text { where, } \mathrm{m}=\text { money multiplier }(\mathrm{M} / \mathrm{B}) \\
& k=\text { arrency ratio }\left(\mathrm{C}^{\mathrm{P}} / \mathrm{D}^{\mathrm{h}}\right. \text { ? } \\
& t=\text { time deposit ratio }\left(\mathrm{T}^{\mathrm{N}} \mathrm{D}^{\mathrm{r}}\right. \text { ) } \\
& g \mathrm{e} \text { Treastary deposit ratio }\left(\mathrm{D}^{\mathrm{t}} / \mathrm{D}^{\mathrm{P}}\right) \\
& r=\text { reserve ratio }\left[R /\left(D^{p}+D^{t}+T\right)\right] \\
& M \perp=\operatorname{money} s \text { stock }\left\{C^{\varphi^{p}} \div \mathrm{D}^{y}\right\} \\
& \mathrm{B}=\text { monetary (somere) base }\left(\mathrm{C}^{\mathrm{p}}+\mathbf{R}\right) \\
& C^{\mathrm{b}}=\text { currency held by monbank public } \\
& D^{\prime \prime}=\text { net demand deposits held by nonbank public } \\
& \mathrm{T}=\text { = time deposits held by nonbank public } \\
& \mathrm{D}^{\prime}==\text { Treastry deposits at commercial banks }\left\{\mathrm{D}^{1} \ldots \mathrm{D}^{\mathrm{tl}}+\mathrm{D}^{\mathrm{in}} \mathrm{j}\right. \\
& D^{1:}=\text { Treasury deposits in regular THL accounts } \\
& \mathrm{D}^{\text {th }}=\text { Treasury deposits in note accounts } \\
& \text { If w bank reserves }
\end{aligned}
$$

A change in Treasury deposits could affect both the $g$-and rratios. We can express the g-and r-ratios as:

(A.3) $\mathrm{g} \cong=\mathrm{D}^{\mathrm{y}} / \mathrm{D}^{\mathrm{Fr}} \cong\left(\mathrm{D}^{\mathrm{a}}+\mathrm{D}^{\mathrm{m}}\right\rangle / \mathrm{D}^{\mathrm{F}}$

$$
\text { (A. f) } \quad r=r^{d}\left[D^{n /} /\left(D^{P}+D^{t}+T\right)\right]+r^{1}\left[T^{m} /\left(D^{P}+D^{t}+T\right)\right]+e+v
$$

where, $\mathrm{r}^{\mathrm{d}}=$ rexpluired reserve ratio against demand deposits

$$
\begin{aligned}
& 1^{\mathrm{m}}=\text { member bank demand deposits subject to reservet } \\
& r^{1}=\text { required reserve ratio against time deposits } \\
& T^{m}=\text { member bank time deposits subject to reserve re- } \\
& \mathrm{e}=\text { excess reserve }\left(\mathrm{R}^{+}\right) \text {ratio }\left[\mathrm{R}^{\mathrm{e}} /\left(\mathrm{D}^{\mathrm{F}}+\mathrm{D}^{\mathrm{t}}+\mathrm{T}\right)\right] \\
& v=\text { nonmember bank valt cash }\langle\mathrm{V}\rangle \text { ratio }\left[\mathrm{V} /\left(\mathrm{D}^{\prime \prime}+\mathrm{D}^{\prime}+\mathrm{T}\right]\right]
\end{aligned}
$$

It is assumed here that desired excess reserves $\left(R^{*}\right)$ and desired nonmember bank vault cash (V) are unchanged by the introduction of TTL note accounts. Excess reserves and nonmember bank vault cash are both non-interest-earning assets of banks. Since banks participating in the TIL note program must pay interest on note balances at a rate 25 basis points below the prevaling federal funds rate, note balances are a relatively expensive source of funds to banks at current interest rates. These note balances must also be fully collateralized by banks' holdings of eligble securities. It is mikely, therefore that an increase in note balances would induce banks to increase their desired holdings of non-interest-earning assets.

The term $\mathrm{D}^{\mathrm{m}}$ is composed of member bank demand deposits subject to reserve requirements, including net demand deposits of the nonbank public ( $D^{\mathrm{mp}}$ ) and regular TTL accounts $\left(D^{n+1}\right)$. The increase in note acounts at the ex. pense of regular TTL accounts decreases member bank required reserves. The decline in required reserves (RR) depends on the required reserve ratio $\left(r^{d}\right)$ and on the amount that regular TTL accounts at member banks decline."

(A.5) $\triangle R R=\mathrm{r}^{\mathrm{d}}\left(\triangle \mathrm{D}^{m} \mathrm{~m}\right)$

However, only the proportion ( $z$ ) of total note balances held at member banks will affect the numerator of the $r$-ratio as regular TTL balances at member banks decline.

(A.6) $\quad \mathrm{D}^{\mathrm{min}}=\mathrm{z} \mathrm{D}^{\mathrm{tn}}$

TTL note accounts ( $D^{\text {th }) ~ m a y ~ i n t i a l l y ~ i n c r e a s e ~ d u e ~ t o ~ a ~}$ transfer of funds from regular TTL accounts $\left(\mathrm{D}^{\text {th}}\right)$ into $\mathrm{Q}^{\text {th }}$ or by a transfer of Treasury deposits at the Fed into $\mathrm{D}^{\mathrm{tn}}$.

(A. $\bar{i}) \Delta \mathrm{D}^{\text {tn }}=-\Delta \mathrm{D}^{\mathrm{a}}+-\Delta$ (Treasury deposits at the Fed

where,

(A.s) $\Delta D^{4}=\Delta D^{n}+\Delta D^{\prime}$

The initial decine in regular TTL balances $\left(\mathrm{D}^{\mathrm{il}}\right.$ ) can be considered to be some proportion $h$ of note balances $\left(D^{(n)}\right)$, so we can write: $-\triangle \mathrm{D}^{\mathrm{n}}=\mathbf{h} \Delta \mathrm{D}^{\mathrm{tn}}$ and consequently, - $\Delta$ (Treasury deposits at the Fed $)=(1-h)\left(\Delta D^{m}\right)$. In particular, the initial decline in regular TTL balances at nember banks $\left(\mathrm{D}^{\mathrm{mll}}\right)$ is considered to be the proportion $h$ of note balances at member banks ( $\mathrm{D}^{\mathrm{mtn}}$ ): $-\Delta \mathrm{D}^{\mathrm{mtl}}=\mathrm{h} \Delta \mathrm{D}^{\mathrm{mtg}}$. Conseguently, we have:

(A.9) $\Delta D^{1}=\Delta D^{n}-h \Delta D^{1 n}=(1-h) \Delta D^{m}$

(A. 10$) \quad \Delta D^{m !}=\Delta D^{m i n}+\Delta D^{m i t k}=(1-h) \Delta D^{m+n}$

We can now express the change in required reserves in equation A.5 as:

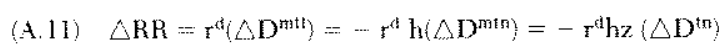

tThe decrease in required reserves as note balances rise will induce banks to expand their loans and deposits. Such deposit expansion will ultimately change the levels of currency and of demand, time, and Treasury deposits. However, the $k$-and t-atios will remain unchanged by this process. 
The effect of the introduction of TTL note accounts on the $g$-and r-ratios are as follows: ${ }^{2}$

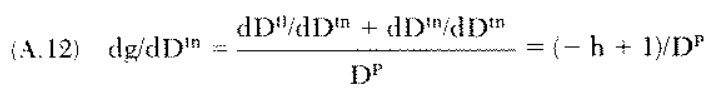

$$
\begin{aligned}
& =(\mathrm{I}-\mathrm{h}) / \mathrm{D}^{\mathrm{p}}>0 \\
& \text { since } 0<h<1 \\
& \text { (A.13) } \mathrm{dr} / \mathrm{dD}^{\mathrm{m}} \approx \frac{\left.\mathrm{dR} / \mathrm{dD}^{\mathrm{tr}}\right)\left(\mathrm{D}^{\mathrm{p}}+\mathrm{D}^{\mathrm{t}}+\mathrm{T}\right)-\left(\mathrm{d} \mathrm{D}^{\mathrm{t}} / \mathrm{dD}^{\mathrm{m}}\right) \mathrm{R}}{\left(\mathrm{D}^{\mathrm{p}}+\mathrm{D}^{\mathrm{t}}+\mathrm{T}\right)^{2}}
\end{aligned}
$$

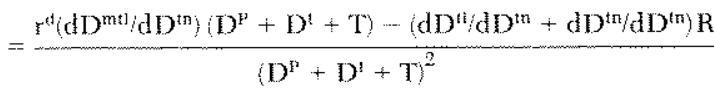

$$
\begin{aligned}
& -\frac{r^{d}(-h)\left(d D^{\min } d D^{\mathrm{tn}}\right)\left(D^{p}+D^{4}+T\right)-(\cdots h+1) \mathrm{R}}{\left(D^{r}+D^{t}+T^{2}\right)^{2}} \\
& =\frac{r^{\mathrm{d}}(-\mathrm{h}) \mathrm{z}\left(\mathrm{D}^{\mathrm{F}}+\mathrm{D}^{\mathrm{t}}+\mathrm{T}\right)-(\mathrm{l}-\mathrm{h}) \mathrm{R}}{\left(\mathrm{D}^{\mathrm{F}}+\mathrm{D}^{\mathrm{t}}+\mathrm{T}\right)^{2}} \\
& =\frac{-z h r^{r t}-(1-h) r}{\left(D^{p}+D^{\prime}+h\right)}<0
\end{aligned}
$$

Thus, the g- and r-ratios change in offsetting ways, and the effect on the multiplier is:

$$
\begin{aligned}
& \text { (A.14) } \mathrm{dm} / \mathrm{d} \mathrm{D}^{\mathrm{tn}}=\frac{-\left[\left(\mathrm{dr} / \mathrm{d} \mathrm{D}^{\mathrm{tn}}\right)(1+\mathrm{t}+\mathrm{g})+\mathrm{r}\left(\mathrm{dg} / \mathrm{d} \mathrm{D}^{\mathrm{tn}}\right]\right](1+\mathrm{k})}{[\mathrm{r}(1+\mathrm{t}+\mathrm{g})+\mathrm{k}]^{3}} \\
& =\frac{-\left[-x h r^{d} / D^{p}-(1-b) r / D^{p}+r(1-h) / D^{P}\right](1+k)}{[r(1+t+g)+k]^{2}} \\
& =\frac{\left(z h r^{d} / D^{p}\right)(1+k)}{[r(1+t+g)+k]^{2}} \\
& >0
\end{aligned}
$$

With appropriate substitutions, equation $A .14$ can be expressed as follows:

(A.15) dm/dD $=\frac{2 h r^{\mathrm{d}} \mathrm{m}}{\mathrm{D}^{\mathrm{P}}[\mathrm{r}(1+\mathrm{t}+\mathrm{g})+\mathrm{k}]}=\frac{2 h \mathrm{z}^{\mathrm{t}} \mathrm{m}}{\mathrm{B}}$

Note that, if the change in the money multiplier is evalnated with respect to note balances ( $\mathrm{D}^{\mathrm{m}}$ ), both the proportion of note balances that result from the decline in regular TTL. balances $(h)$ and the proportion of total note balances at member banks (z) must be evaluated. The effect of introducing note accounts on the money multiplier is then

\footnotetext{
${ }^{2}$ In what follows, the expression dxidy represents the partial derivative of $x$ with respect to $y$
}

equation A.15 times the change in note balances. Alter natively, the change in the multiplier could be taken with respect to the change in regular $T \mathrm{TL}$ balances subject to reserve requirements $\left(D^{m m}\right)$. This can be clone since the only effects of $D^{\text {th }}$ on the multiplier that do not offset each other in equation A.14 operate on the r-ratio via the reduction in regular TTL accounts at nember banks $\left(D^{\text {rat }}\right)$.] This yields the expression:

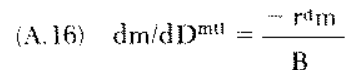

The effect on the money multiplier can then be estimated by equation A.16 times the decline in regular TTL balances subject to reserve requirements. The effect on the multiplier is equivalent to that obtained using equation A.15, but the proportions hand $z$ need not be evalnated

The effect on the money stock (Ml) of introducing note accounts is a combination of the change in the multiplier and the change in the monetary (source) base that results from the decline in Treasury deposits at the Fed.

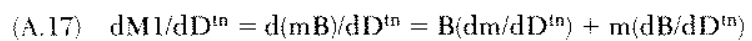

The dollar change in the base that occurs as TTL note balances increase is equal to the proportion of note balances that result from the decline of Treasury deposits at the Fed $(1-h)$ times the dollar change in note balances $[\triangle B=$ $\left.(\mathrm{l}-\mathrm{h})\left(\Delta \mathrm{D}^{\mathrm{tn}}\right)\right]$. The chollar change in the money stock due to the effect of note accounts on the base alone is then:

(A.18) $\triangle M I=m(\triangle B)=m(1-h)\left\langle\Delta D^{\text {tn }}\right.$

This assumes, of course, that the shift of Treasury deposits at the Fed to note accounts is not of set by defensive open market operations.

The dollar change in the money stock due to the effect of note accounts on the money multiplier alone is the monetary base (B) times equation A.15 times the dollar increase in note balances. Alternatively, this can be expressed in terms of the dollar decrease in regular TTL balances at member banks using equation A. 16 as follows:

$$
\begin{aligned}
& \text { (A. 19) } \triangle \mathrm{Ml}=\mathrm{B}\left(\mathrm{dm} / \mathrm{d} \mathrm{D}^{\mathrm{m}}\right)\left(\Delta \mathrm{D}^{\mathrm{m}}\right) \\
& \left.=B\left(\mathrm{dm} / \mathrm{d} D^{\mathrm{mt}}\right) / \triangle D^{\mathrm{m} \neq 1}\right\} \\
& =-\mathrm{B}\left(\mathrm{r}_{\mathrm{d}}^{\mathrm{m}} / \mathrm{B}\right)\left(\triangle \mathrm{D}^{\mathrm{m} d}\right) \\
& \left.=-r^{\mathrm{d}} \mathrm{m} / \Delta D^{\mathrm{mt}}\right)
\end{aligned}
$$

This is the expression used in the text to estimate the effect on the money stock of introducing note accounts, due to the impact of the change in the nultiplier alone. 